\title{
Non-Conformity to Social Distancing Rules Give Rise to Various COVID-19 Clusters in Malaysia ${ }^{\dagger}$
}

\author{
Che Ghazali Norul Hajar ${ }^{1, *}{ }^{\mathbb{D}}$, Sabreena Safuan ${ }^{1}{ }^{\mathbb{D}}$, Nor Fazila Che Mat ${ }^{1} \mathbb{D}$, \\ Mohammad Khairul Azhar Abdul Razab ${ }^{1}\left(\mathbb{D}\right.$, Siddhartha Pati ${ }^{2}$, , Bryan Raveen Nelson ${ }^{3}(\mathbb{D}$ \\ and Hisham Atan Edinur 1,3,*(D)
}

Citation: Hajar, C.G.N.; Safuan, S.; Mat, N.F.C.; Razab, M.K.A.A.; Pati, S.; Nelson, B.R.; Edinur, H.A.

Non-Conformity to Social Distancing Rules Give Rise to Various COVID-19 Clusters in Malaysia. Med. Sci. Forum 2021, 4, 3. https://doi.org/10.3390/ ECERPH-3-08990

Academic Editor: Jon Øyvind Odland

Published: 11 January 2021

Publisher's Note: MDPI stays neutral with regard to jurisdictional claims in published maps and institutional affiliations.

Copyright: (c) 2021 by the authors. Licensee MDPI, Basel, Switzerland. This article is an open access article distributed under the terms and conditions of the Creative Commons Attribution (CC BY) license (https:// creativecommons.org/licenses/by/ $4.0 /)$.
1 School of Health Sciences, Health Campus Universiti Sains Malaysia, Kubang Kerian 16150, Malaysia; sabreena@usm.my (S.S.); fazilacm@usm.my (N.F.C.M.); khairul.azhar@usm.my (M.K.A.A.R.)

2 Centre of Excellence, Khallikote University, Berhampur 761008, India; patisiddhartha@gmail.com

3 Institute of Tropical Biodiversity and Sustainable Development, Universiti Malaysia Terengganu, Kuala Terengganu 21030, Malaysia; bryan.nelson@umt.edu.my

* Correspondence: erina_86my@yahoo.com (C.G.N.H.); edinur@usm.my (H.A.E.); Tel.: +60-9-7677518 (C.G.N.H.); +60-9-7677641 (H.A.E.)

+ Presented at the 3rd International Electronic Conference on Environmental Research and Public Health-Public Health Issues in the Context of the COVID-19 Pandemic, 11-25 January 2021; Available online: https:/ / ecerph-3.sciforum.net/.

\begin{abstract}
Coronavirus disease 19 (COVID-19) can be transmitted via contact with affected individuals and social distancing is widely practiced as a public preventive measure to contain the disease. Social distancing implementation includes maintaining at least one-meter distance between every individual, avoiding mass gatherings and staying out of crowded places. To ensure successful implementation of social distancing, many countries including Malaysia have opted for Movement Control Order (MCO). Under MCO, mass assembly of cultural, religious, and social events are prohibited, education institutions, government, and public premises are closed and there are strict restrictions on leaving and entering the country. Here, we report on several clusters of COVID-19 cases in Malaysia that emerged due to non-conformity toward social distancing. Our report thus provides information for policy makers for designing a better pandemic response plan in the country.
\end{abstract}

Keywords: COVID-19 clusters; movement control order; social-distancing; COVID-19 spread; disease prevention

\section{Introduction}

The spreading of Coronavirus disease 19 (COVID-19) was declared a Public Health Emergency of International Concern by the World Health Organization (WHO) on 30 January 2020, and by 11 March 2020 it had emerged to become a pandemic due to international mobility. At present, 41.1 million cases with 1.13 million deaths are reported worldwide, either after inhaling or having contact with respiratory droplets (coughing or sneezing) of infected individuals [1]. This disease is caused by a new coronavirus strain termed as severe acute respiratory syndrome coronavirus 2 (SARS-CoV-2) which shared 79.5 percent homology with the previously identified SARS-CoV [2,3]. In the absence of specific drugs or vaccination against SARS-CoV-2, social distancing, personal hygiene and wearing personal protective equipment (PPE) were introduced as advisory interventions to delay the spreading of COVID-19. Social distancing was shown to be an effective way to slow down or prevent the spread of COVID-19. In fact, this public health advisory was used successfully with SARS-CoV in 2002 and Middle East respiratory syndrome coronavirus (MERS-CoV) in 2012 [4,5]. 
Social distancing is a general recommendation by the Center for Disease Control and Prevention (CDC) to contain COVID-19 [6] with adoptions such as $1 \mathrm{~m}$ distance between every individual, refraining from mass gatherings, avoiding of crowded places and the use of contactless technology in services and operations. Therefore, Malaysia adapted the social distancing recommendation into their Movement Control Order (MCO) by encouraging its citizens to stay at home, in which essential sectors such as resources (grocery), services (telecommunication, insurance, finance and banking), productions (food and merchandise) and medical services are allowed to operate with strict protocols, public gatherings were banned, while the education sector uses e-learning and every other sector uses online communication via Webex, Zoom, Google Meet, Skype, etc., to resume operations. These community mitigation measures have been proven effective in flattening COVID-19 the transmission curve and in delaying the exponential spread of SARS-CoV-2 [7,8]. Despite that, $\mathrm{MCO}$ and thus social distancing compliance in Malaysia is not 100 percent, giving rise to various COVID-19 clusters in the country [9]. Thus, this paper will focus on the effect of non-conformity to social distancing rules on the COVID-19 incidence rate and clusters of infection in Malaysia.

\section{Materials and Methods}

Our data collection is based on rapid released analysis by Daily Press Conference from Ministry of Health $(\mathrm{MOH})$ Malaysia, $\mathrm{MOH}$ website, newspaper reports, as well as observation on trusted social media platforms. The latter includes social media posting from government and relevant stakeholders, e.g., Facebook posting from the National Crisis Preparedness and Response Centre (CPCR) and MOH Malaysia. In the Daily Press Conference, the Director-General of Health updates new cases, new recovered cases, new deaths, and total confirmed cases together with the presence of new and active clusters along with their origins for the entire Malaysia (13 states and three federal territories). Data collection also includes a search of the literature related to COVID-19 articles in Malaysia. String words such as 'COVID-19', 'ministry of health', 'cases', 'recovery', 'hospital', 'movement control', 'fines', 'mass gathering', 'social distancing', 'Malaysia' and 'enforcement' weree used independently and together during the literature search in Scopus, PubMed, or Google Scholar.

\section{Results}

At the time of writing, Malaysia is experiencing an increasing number of daily new COVID-19 cases which is due to both sporadic and cluster cases. On 29 April 2020, 5945 COVID-19 cases are reported in Malaysia where 4300 (72\% of total COVID-19 patients) of these cases have clustering origin (Table 1 and Figure 1). The highest number of COVID-19 cases were linked to the Sri Petaling cluster (2287 cases) that occurred due to a large-scale religious event in Kuala Lumpur from 27th February to 1 March 2020 [9]. This followed by Hulu Langat, Pesantren and Kluang clusters, all with three digit cumulative cases. Altogether, there were four MCO phases in Malaysia-phase I from 18 March to 31 March 2020, phase II from 1 April to 14 April, phase III from 15 April to 28 April 2020, and phase IV from 29 April to 12 May 2020-that were enforced to reduce disease clustering and prevent the widespread of COVID-19 disease [9]. 
Table 1. Details of COVID-19 clusters in Malaysia [10].

\begin{tabular}{|c|c|c|c|}
\hline No. & Cluster & $\begin{array}{c}\text { Cluster Identified } \\
\text { (Announced by MOH) }\end{array}$ & Expected Origin \\
\hline 1 & Sri Petaling & 14 March 2020 & Unidentified \\
\hline 2 & Bandar Baru Bangi & 6 April 2020 & Unidentified \\
\hline 3 & Person Under Investigation (Italy) & 6 April 2020 & Import \\
\hline 4 & Religious Assembly (Sarawak) & 6 April 2020 & Unidentified \\
\hline 5 & Person Under Investigation (Bali) & 13 April 2020 & Import \\
\hline 6 & Health Staff (Sabah) & 18 April 2020 & Wedding gathering, Ipoh \\
\hline 7 & Magetan Student (Indonesia) & 19 April 2020 & Import \\
\hline 8 & Pengerang & 22 April 2020 & Personal activities (Cross State) \\
\hline 9 & Malayan Mansion & 7 April 2020 & Sri Petaling \\
\hline 10 & Selangor Mansion & 7April 2020 & Sri Petaling \\
\hline 11 & Menara City One & 8 April 2020 & Sri Petaling \\
\hline 12 & Hulu Langat & 30 March 2020 & Sri Petaling \\
\hline 13 & Kluang & 27 March 2020 & Sri Petaling \\
\hline 14 & Sarawak General Hospital & 29 April 2020 & Religious Assembly (Sarawak) \\
\hline 15 & Sendayan & 14 April 2020 & Sri Petaling \\
\hline 16 & Lanchang & 2 May 2020 & Sri Petaling \\
\hline 17 & KL Wholesale Market & 19 April 2020 & Sri Petaling \\
\hline 18 & Construction & 3 May 2020 & KL Wholesale \& Kampung Baru \\
\hline 19 & Kampung Baru & 14 April 2020 & Sri Petaling \\
\hline 20 & Chow Kit Market & 24 April 2020 & Sri Petaling \\
\hline 21 & Selayang Baru & 28 April 2020 & Sri Petaling \\
\hline 22 & Pesantren & 21 April 2020 & Indonesia \\
\hline 23 & Bahau Market & 26 April 2020 & KL Wholesale \\
\hline 24 & Jalan Othman Market & 27 April 2020 & Sri Petaling \\
\hline 25 & *Madrasah Sungai Lui & 12 April 2020 & Sri Petaling \\
\hline 26 & ${ }^{*}$ Health Staf (Kuching) & 15 April 2020 & Religious Assembly (Sarawak) \\
\hline 27 & *Pedas & 8 April 2020 & Rembau \\
\hline 28 & Madrasah Jerantut & 12 April 2020 & Sri Petaling \\
\hline 29 & Madrasah Penanti & 12 April 2020 & Sri Petaling \\
\hline 30 & Madrasah Jasin & 12 April 2020 & Sri Petaling \\
\hline 31 & Rembau & 8 April 2020 & Sri Petaling \\
\hline
\end{tabular}

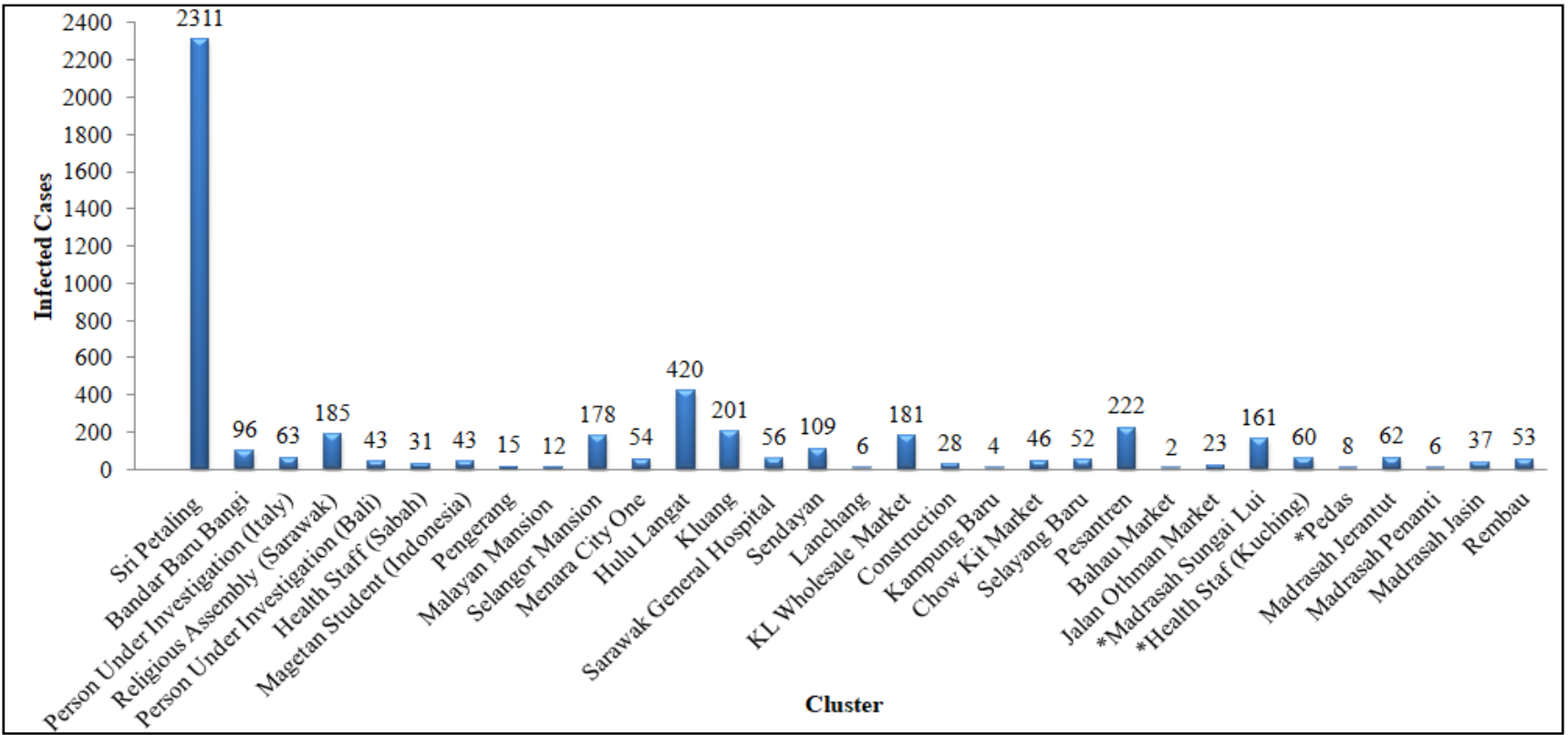

Figure 1. COVID-19: Number of infected cases against the number of clusters that develop from disobedience during social distancing. 


\section{Discussion}

The WHO launched the "2019 Novel Coronavirus (2019-nCoV): Strategic Preparedness and Response Plan" on 3 February 2020 which contains mitigation strategies to detect and contain the massive spread of COVID-19 via human to human transmission. The plan was also designed to reduce negative impacts of COVID-19 on social, economic, and healthcare settings [11]. Four transmission scenarios for COVID-19 were proposed by WHO (i.e., no reported cases, sporadic cases, cluster of cases, and community transmission) and each country can then adjust their preventive measures based on local context [12]. In general, preventive responses such as case finding, contact tracing, and quarantine can be applied in all transmission scenarios but should be intensified with the increasing number of positive COVID-19 cases. For example, travel and movement restrictions can be adopted as part of quarantine procedures in countries with community outbreak because contact tracing and isolation may no longer sufficient to stop transmission and disease spread [13].

In Malaysia, an increasing number of daily new COVID-19 cases were observed starting from March 2020 which indicated the failure of social distancing in the country as a preemptive strategy to reduce the risk of COVID-19 spread $[10,14]$. This is particularly true because mass gathering associated with cultural and religious events that lead to cluster cases such as Sri Petaling, Simpang Rengam, and Bangi took place after the first COVID-19 case was recorded in the country, which was on the 25 February 2020. Several clusters of COVID-19 cases were also detected during the MCO which further reflected the non-compliance to social distancing. Thus, the Malaysian government introduced an enhanced MCO (i.e., CMCO from 13 May to 9 June) in point-sources experiencing massive COVID-19 outbreaks where strict enforcement (army and barricades) successfully broke the spread chains [15]. In addition, the introduction of a mobile application (MyTrace) by the Ministry of Science, Technology and Innovation (Malaysia) has improved the contact tracing measures while also providing awareness to persons that may have contact with COVID-19 infected [16]. MyTrace uses Bluetooth technology to measure distances between every MyTrace user. [17]. A similar application (TraceTogether) was released by Singapore on 20 March 2020 and it was successful to indicate the presence of COVID-19 infected individuals with a sensitivity of up to $2 \mathrm{~m}$ [18]. Both MyTrace and TraceTogether mobile applications encourage users to keep their social distancing so that contact tracing breaks COVID-19 spreading in all communities.

After a series of MCOs and CMCOs that lasted continuously for nearly three months, Malaysia brought its COVID-19 curve into a continuous flat $[9,15]$. This was because the government obeyed the preventive measures recommended by the WHO [10]. Discipline from members of the public would have shortened the duration of the MCO and produced a smaller number of infected cases, such as presented by Thailand, Vietnam, Cambodia, Myanmar and Brunei [19-21]. It was non-compliance towards social distancing that spawned clustering cases and the need to implement enforcement during the MCO and EMCO. Therefore, public preventive measures such as social distancing, hand hygiene and personal protection devices together with $\mathrm{MCO}$ and $\mathrm{EMCO}$ can be adopted for future outbreaks. Currently, Malaysia is under recovery MCO (i.e., RMCO from 10 June to 31 December 2020) with the primary aim to stimulate economic growth [22]. The lifting of $\mathrm{MCO}$ and $\mathrm{CMCO}$ opened the borders of Malaysia for local and international mobility. Unfortunately, in October 2020, thousands of Malaysians were becoming infected with COVID-19 linked to hundreds of COVID-19 clusters detected in states such as Sabah, Kedah, Selangor and Putrajaya [10].

\section{Conclusions}

Overall, our study supports the importance of social distancing to contain COVID-19. However, the effectiveness of this preventive measure depends on the great support from the public. In Malaysia, non-conformity to social distancing has given rise to various COVID-19 clusters even after the enforcement of MCO. Therefore, our report provides an informed decision to policy makers for designing a better pandemic response plan in the country. 
Author Contributions: Conceptualization, C.G.N.H., S.S. and H.A.E.; methodology, N.F.C.M. and M.K.A.A.R.; formal analysis, M.K.A.A.R.; investigation, C.G.N.H., N.F.C.M. and M.K.A.A.R.; resources, C.G.N.H., S.S., M.K.A.A.R., S.P. and B.R.N.; data curation, C.G.N.H., S.S. and M.K.A.A.R.; writing-original draft preparation, C.G.N.H., S.P., B.R.N. and H.A.E.; writing-review and editing, C.G.N.H., S.P., B.R.N. and H.A.E. All authors have read and agreed to the published version of the manuscript.

Funding: This research received no external funding.

Acknowledgments: We would like to acknowledge Universiti Sains Malaysia and Universiti Malaysia Terengganu for research and financial supports.

Conflicts of Interest: The authors have no competing or conflicting interests.

\section{References}

1. World Health Organization. Available online: https://www.who.int/emergencies/diseases/novel-coronavirus-2019/situationreports (accessed on 23 April 2020).

2. Keshtkar-Jahromi, M.; Sulkowski, M.; Holakouie-Naieni, K. Public Masking: An Urgent Need to Revise Global Policies to Protect against COVID-19. Am. J. Trop. Med. Hyg. 2020, 102, 1160-1161. [CrossRef] [PubMed]

3. Guo, Y.R.; Cao, Q.D.; Hong, Z.S.; Tan, Y.Y.; Chen, S.D.; Jin, H.J.; Tan, K.S.; Wang, D.Y.; Yan, Y. The origin, transmission and clinical therapies on coronavirus disease 2019 (COVID-19) outbreak-an update on the status. Mil. Med. Res. 2020, 7, 1-10. [CrossRef] [PubMed]

4. To, K.K.W.; Hung, I.F.N.; Chan, J.F.W.; Yuen, K.Y. From SARS coronavirus to novel animal and human coronaviruses. J. Thorac. Dis. 2013, 5, S103. [CrossRef] [PubMed]

5. World Health Organization. Available online: https://www.who.int/csr/disease/coronavirus_infections/faq/en/ (accessed on 23 April 2020).

6. Centres for Diseases Control and Prevention. Available online: https://www.cdc.gov/coronavirus/2019-ncov/downloads/ community-mitigation-strategy.pdf (accessed on 23 April 2020).

7. Ebrahim, S.H.; Ahmed, Q.A.; Gozzer, E.; Schlagenhauf, P.; Memish, Z.A. Covid-19 and community mitigation strategies in a pandemic. BMJ 2020, 368, m1066. [CrossRef] [PubMed]

8. Matrajt, L.; Leung, T. Evaluating the effectiveness of social distancing interventions to delay or flatten the epidemic curve of coronavirus disease. Emerg. Infect. Dis. 2020, 26, 1740-1748. [CrossRef] [PubMed]

9. Mat, N.F.C.; Edinur, H.A.; Razab, M.K.A.A.; Safuan, S. A single mass gathering resulted in massive transmission of COVID-19 infections in Malaysia with further international spread. J. Travel. Med. 2020, 27, taaa059. [CrossRef] [PubMed]

10. Ministry of Health Malaysia. Available online: http://www.moh.gov.my/index.php/pages/view/2019-ncov-wuhan (accessed on 7 May 2020).

11. World Health Organization. Available online: https://www.who.int/docs/default-source/coronaviruse/srp-04022020.pdf (accessed on 7 May 2020).

12. World Health Organization. Available online: https://apps.who.int/iris/rest/bitstreams/1272587/retrieve (accessed on 23 April 2020).

13. World Health Organization. Available online: https://apps.who.int/iris/bitstream/handle/10665/259884/9789241513623-eng. pdf;jsessionid=204ACE5B78E01D2A0FA7A3C6BCDE9468? sequence=1 (accessed on 23 April 2020).

14. Yezli, S.; Khan, A. COVID-19 pandemic: It is time to temporarily close places of worship and to suspend religious gatherings. J. Travel. Med. 2020, 28, taaa065. [CrossRef] [PubMed]

15. New Straits Times. Available online: https://www.nst.com.my/news/nation/2020/03/579651/emco-enforced-kl-skyscraper-32 00-affected (accessed on 23 April 2020).

16. TheStar. Available online: https://www.thestar.com.my/news/nation/2020/05/08/data-from-covid-19-app-mytrace-kepton-phone-not-govt-servers-says-khairy (accessed on 23 April 2020).

17. Astro Awani. Available online: http://www.astroawani.com/berita-malaysia/covid-19-malaysia-siapkan-aplikasi-telefonpintar-kesan-pergerakan-individu-235458 (accessed on 23 April 2020).

18. TheStar. Available online: https://www.thestar.com.my/tech/tech-news/2020/03/20/covid-19-singaporelaunches-contacttracing-mobile-app-to-track-coronavirus-infections (accessed on 23 April 2020).

19. World Health Organization. Available online: https://www.who.int/docs/default-source/coronaviruse/situation-reports/2020 0505covid-19-sitrep-106.pdf?sfvrsn=47090f63_2 (accessed on 23 April 2020).

20. Dinh, L.; Dinh, P.; Nguyen, P.D.; Nguyen, D.H.; Hoang, T. Vietnam's response to COVID-19: Prompt and proactive actions. J. Travel. Med. 2020, 27, taaa047. [CrossRef] [PubMed]

21. Wong, J.; Abdul Aziz, A.B.; Chaw, L.; Mahamud, A.; Griffith, M.M.; Lo, Y.R.; Naing, L. High proportion of asymptomatic and presymptomatic COVID-19 infections in travelers and returning residents to Brunei. J. Travel. Med. 2020, 27, taaa066. [CrossRef] [PubMed]

22. Malay Mail. Available online: https://www.malaymail.com/news/malaysia/2020/06/07/pm-cmco-to-be-replaced-withrecovery-movement-control-order-with-further-re/1873225 (accessed on 18 July 2020). 